\title{
Rewolucja lupkowa: Światowe rynki gazu i ropy naftowej w warunkach transformacji ${ }^{1}$
}

\section{Wprowadzenie}

Rewolucja łupkowa rozpoczęła się w Stanach Zjednoczonych mniej niż dziesięć lat temu; do szybko rosnącej produkcji gazu niekonwencjonalnego kilka lat później dołączyła produkcja ropy niekonwencjonalnej. Proces ten znajduje się ciągle w fazie początkowej i kompetentni obserwatorzy wskazują na istotne zmiany w ciągu najbliższych dziesięcioleci. Przewiduje się rozszerzenie rewolucji na cały świat, co ma doprowadzić do poważnych skutków ekonomicznych i geopolitycznych tak dla krajów produkujących energię, jak i jej odbiorców. Starając się połączyć poszczególne zagadnienia, prezentowana praca analizuje przeszłość, teraźniejszość i przyszłość rozwoju gazu i ropy naftowej z łupków. Jej celem jest przybliżenie tych ekscytujących wydarzeń.

Rozważane w niniejszej pracy zagadnienia zostały zorganizowane w następujący sposób: krótki rozdział pierwszy określa definicje gazu niekonwencjonalnego i ropy niekonwencjonalnej, które to pojęcia określa się w niniejszym tekście jako gaz i ropa „z łupków”. Wydobycie gazu i ropy z łupków opiera się na wykorzystaniu tej samej technologii, która została pokrótce opisana.

* Curtin University, GPO Box 1987 Perth WA 6845, Australia; e-mail: r.aguilera@curtin.edu.au

** Luleí University of Technology, Sweden; e-mail: marian@radetzki.biz

\footnotetext{
1 Artykuł jest tłumaczeniem na język polski artykułu autorów opublikowanego w języku angielskim
} w Mineral Economics, vol. 26, 2014. 
W dalszej części artykuł przedstawia aktualne osiągnięcia. Rozdział drugi przeciwstawia historyczne, spadające poziomy wydobycia gazu i ropy naftowej w USA oraz uzyskiwane ostatnio poziomy produkcji, po tym jak „rewolucja” nabrała tempa. Uwzględnia się tutaj również zmiany w wielkości amerykańskiej bazy zasobów wydobywalnych od czasu gdy zasoby w łupkach stały się ekonomicznie opłacalne. Rozdział trzeci bada aktualny wpływ rewolucji łupkowej na rynki energii w USA i na całym świecie. Rozdział czwarty rozważa ogólne skutki gospodarcze dla Stanów Zjednoczonych związane ze wzrostem poziomu produkcji gazu i ropy naftowej.

Pozostała część pracy ma bardziej teoretyczny charakter, ponieważ odnosi się do przyszłości. Rozdział piąty jest poświęcony przewidywanym osiągnięciom produkcyjnym Stanów Zjednoczonych, podczas gdy rozdział szósty najpierw wymienia przyczyny, dla których Stany Zjednoczone prowadzą w tej dziedzinie, a następnie rozszerza perspektywę, otwierając drogę do rozważań co i gdzie wydarzy się, gdy reszta świata pokona swoje obawy i ograniczenia i podejmie odpowiednie działania. Rozdział siódmy, końcowy, szkicuje konsekwencje pomyślnie rozwijającej się rewolucji łupkowej dla polityki światowych rynków energetycznych i rozważa jej geopolityczne i ekonomiczne konotacje.

\section{Definicje i charakterystyka techniczna}

Rewolucja łupkowa jest wynikiem postępu technologicznego, za którego przyczyną eksploatacja ogromnych, wcześniej niezagospodarowanych złóż ropy i gazu, stała się ekonomicznie opłacalna. Zasoby będące $\mathrm{w}$ centrum uwagi niniejszej pracy, określane terminami takimi jak gaz z łupków (shale gas), metan z pokładów węgla (coalbed methane) oraz gaz zamknięty (tight gas) i ropa zamknięta (tight oil) zazwyczaj nie są ściśle zdefiniowane i często poszczególne terminy nakładają się na siebie (EIA 2013a). Jednakże wszystkie one charakteryzują się niską przepuszczalnością, skutkującą niewystarczającymi, z ekonomicznego punktu widzenia, przepływami z pionowych wierceń, które są powszechnie stosowane w przypadku tradycyjnych złóż ropy i gazu (Stevens 2012). W celu uproszczenia, praca opiera się na ustaleniach najnowszych konwencji (DERA 2012) i stąd też wszelkie surowce tego typu określa terminami gaz z łupków i ropa z łupków.

Wszystkie zasoby zlokalizowane w łupkach są określane jako „niekonwencjonalne”. Jednakże, należy podkreślić, że termin „niekonwencjonalne” jest szeroki i zawiera wiele kategorii zasobów innych niż określone powyżej zasoby gazu i ropy z łupków. Stąd też określenie „niekonwencjonalne”, jako subiektywne i niestabilne w czasie, jest unikane w dalszej części pracy.

Przemysł energetyczny wykorzystuje zróżnicowane - często wprowadzające w błąd jednostki miary przy określaniu ilości i wartości. Aby zachować jednolitość i prostotę, niniejsza praca systematycznie przestrzega dominujących konwencji przyjętych przez BP Statistical Review of World Energy (BP Annual). Wszystkie wielkości, dotyczące gazu ziemnego i ropy naftowej, są podane w tonach ekwiwalentu ropy naftowej (toe). 
Ceny gazu i koszty z nim związane wyrażone są w dolarach amerykańskich za milion BTU (USD/MBtu), podczas gdy ceny i koszty dla ropy naftowej są podane w dolarach amerykańskich za baryłkę (USD/bl). Konwersje do powszechnie stosowanych, alternatywnych jednostek miar są podane poniżej.

Ilości ropy i gazu:

1 toe $=7,3$ baryłek ropy $=1110 \mathrm{~m}^{3}$ gazu $=39200$ stóp sześciennych gazu

1 baryłka ropy $(\mathrm{bbl})=42$ galony $\mathrm{US}=158,98731$

Przepływy z ropy naftowej i gazu:

1 bilion stóp sześciennych gazu/rok $=2,74$ miliarda stóp sześciennych gazu na dzień $=$ $=26$ milionów toe/rok

1 stopa $(1 \mathrm{ft})=0,3048 \mathrm{~m}$

Wartości gazu: $\quad 1$ stopa sześcienna $=0,0283 \mathrm{~m}^{3}$

$10 \mathrm{USD} / \mathrm{MBtu}=10 \mathrm{USD} /$ tysiąc stóp sześciennych $=10 \mathrm{USD} /$ gigadżul $=360 \mathrm{USD} /$ tysiąc $\mathrm{m}^{3}$

$$
1 \mathrm{Btu}=1,055 \mathrm{~kJ}
$$

Wartości ropy i gazu:

$$
100 \mathrm{USD} / \mathrm{bbl}(\text { ropa })=730 \mathrm{USD} / \text { ton }(\text { ropa })=18,5 \mathrm{USD} / \mathrm{MBTU}(\mathrm{gaz})
$$

Eksploatacja złóż zlokalizowanych w łupkach stała się powszechnie opłacalna wraz $\mathrm{z}$ zastosowaniem technologii obejmujących wiercenia poziome i szczelinowanie hydrauliczne, co pozwala na uwolnienie węglowodorów ze znacznie większego obszaru niż było to możliwe w przypadku tradycyjnego wiercenia pionowego. Próg rentowności uzależniony jest przede wszystkim od jakości łupków. Właściwości geologiczno-inżynierskie, takie jak wielkość złóż gazu i ropy, głębokość ich zalegania, przepuszczalność, porowatość, saturacja, zawartość substancji organicznej czy ciśnienie panujące w złożu są podstawowymi determinantami, mającymi wpływ na ekonomikę przedsięwzięć łupkowych (Orangi i in. 2011).

Technologie wierceń poziomych i szczelinowania zostały opracowane w USA w latach czterdziestych XX w., ale ich zastosowanie było dość ograniczone, dopóki nie zostały udoskonalone na przełomie stulecia. To, co jest nowe i niezwykłe, to innowacja związana z rozwojem technologii wierceń odwiertów poziomych, które mogą być hydraulicznie szczelinowane wielostopniowo przy zachowaniu odległości od 200, 100, a ostatnio nawet mniej 
niż 50 metrów, co powala uzyskać ponad 60 szczelinowań na odwiert (Aguilera i in. 2012). To, w połączeniu z możliwością wierceń wielokierunkowych i monitorowania przyrostu szczelin metodami mikrosejsmicznymi, doprowadziło do rewolucji łupkowej. W konsekwencji spowodowało to znaczący wzrost wydobycia zasobów będących przedmiotem badań prezentowanej pracy, który jak dotychczas znacznej mierze dotyczy jedynie Stanów Zjednoczonych.

W porównaniu z tradycyjną produkcją węglowodorów, eksploatacja z łupków charakteryzuje się dużą wydajnością odwiertów w pierwszym roku, po czym następują bardzo ostre spadki. Produkcja w drugim roku spada przeciętnie o $40 \%$ i o $50 \% \mathrm{w}$ trzecim roku, z kolejnymi spadkami w ciągu następnych dziesięciu lat produkcji (IEA 2009). Oznacza to konieczność uruchamiania licznych nowych odwiertów w celu utrzymania wydobycia na stałym poziomie oraz dostosowania jego wielkości do zmieniających się cen. Oznacza to również konieczność uzyskania krótkich okresów zwrotu nakładów inwestycyjnych dla każdego odwiertu. Powoli staje się zrozumiałym, że nowa technologia może być również stosowana przy wydobyciu węglowodorów z zasobów tradycyjnych, co znacząco zwiększy jej wydajność (Martin 2009; Maugeri 2013; Schlumberger 2013).

Metody wykorzystywane przy eksploatacji zasobów węglowodorów z łupków wzbudziły powszechne obawy o środowisko naturalne. Przykładowo, praca Howarth i in. (2011) stwierdza, że: w czasie funkcjonowania odwiertu eksploatujacego gaz z formacji łupkowych od 3,6\% do 7,9\% metanu przedostaje sie do atmosfery z systemu odbioru gazu oraz w wyniku nieszczelności. Te emisje metanu sq co najmniej o 30\%, a prawdopodobnie ponad dwukrotnie większe niż w przypadku gazu konwencjonalnego. Z drugiej strony, badanie przeprowadzone przez Burnham i in. (2012) dowodzi, że poziom emisji w cyklu życia gazu z tupków jest o $6 \%$ niższy niż w przypadku konwencjonalnego gazu ziemnego, 23\% niższy niż w przypadku benzyny i 33\% niższy niż w przypadku wegla. Według Jiang i in. (2011): szacunkowe poziomy emisji gazów cieplarnianych dla gazu tupkowego z formacji Marcellus sq zbliżone do tych, jakie aktualnie charakteryzuja rodzimy surowiec. O'Sullivan i Paltsev (2012), na podstawie danych z 4000 poziomych odwiertów gazu w formacjach łupkowych, twierdzą, że sugerowanie, iż szczelinowanie hydrauliczne znaczqco zmienito ogólny poziom emisji gazów cieplarnianych pochodzacych z produkcji gazu ziemnego jest błędne. Co więcej, istnieje wiele innych badań, których opinie i wnioski zmierzają w różnych kierunkach.

Kwestie środowiskowe zostały również podniesione w związku z tematem nadmiernego wykorzystania wody słodkiej i skażenia warstw wodonośnych podczas procesu szczelinowania. Jednakże poczyniono postępy w dziedzinie oczyszczania wody po procesie szczelinowania, dzięki czemu pewne ich ilości mogą być ponownie wykorzystane (Nicot i Scanlon 2012). Nastąpiły również postępy w projektowaniu odwiertów, ich obudowie oraz cementowaniu, co zapobiega przedostawaniu się wody i metanu z odwiertu (Brantley i Meyendorff 2013). Osobną kwestią jest sam proces szczelinowania i rodzaj stosowanych w nim płynów szczelinujących. W przypadku zastosowania zbyt wysokiego ciśnienia, jeśli naprężenia górotworu nie są w pełni zbadane lub formacja jest stosunkowo płytka i znajduje się 
w pobliżu zbiornika wód gruntowych, pęknięcie może rozciagać się do poziomu wód gruntowych (Ripple 2011). Biorąc pod uwagę, że większość formacji łupkowych zawierających gaz znajduje się stosunkowo głęboko i znacznie poniżej formacji wodonośnych, ten negatywny scenariusz jest relatywnie mało prawdopodobny. Potwierdzają to dane na temat procesu szczelinowania uzyskane z tysięcy pomiarów mikrosejsmicznych (Fisher i Warpinski 2011). Porównując górny zasięg wpływu szczelinowania z głębokością zalegania warstw wodonośnych łatwo dojść do wniosku, że możliwość dotarcia szczelin do poziomu wód gruntowych jest znikoma. Przemysł wydobywczy nauczył się już jak kontrolować zasięg i kierunek tworzonych szczelin. Biorąc pod uwagę, że dominujące naprężenia główne zmieniają się wraz ze zbliżaniem się do powierzchni gruntu z pionowych (na głębokości zbiornika) na poziome, prawdopodobieństwo połączenia się szczelinowania hydraulicznego z poziomem wód gruntowych staje się jeszcze mniejsze (Aguilera i in. 2012).

Oprócz wody i piasku, setki substancji chemicznych zawartych w płynie szczelinującym zostaje wpompowywanych do odwiertu. Jednakże te chemikalia zazwyczaj stanowią mniej niż 3\% (obecnie poniżej 1\%) wpompowywanej objętości. Jeśli operator przestrzega odpowiednich procedur, żadna z tych substancji nie powinna przedostać się do wód gruntowych. Co ważne, w wyniku licznych badań powstały zalecenia na temat jakie regulacje są potrzebne w rozwoju przemysłu wydobywczego z formacji łupkowych (IEA 2012a; US DOE 2011; Hunter 2011). Identyfikują one konkretne środki - głównie polegające na kontroli społecznej - w celu zmniejszenia negatywnego wpływu na środowisko i zapewnienia bezpieczeństwa wydobycia. Podsumowując, można stwierdzić, że przy zachowaniu odpowiednich procedur, korzyści ekonomiczne i środowiskowe z łupków prawdopodobnie znacznie przewyższą wszelkie dodatkowe koszty środowiskowe związane z wydobyciem gazu lupkowego.

\section{Dotychczasowe osiągnięcia Stanów Zjednoczonych}

Rysunek 1 przedstawia historyczne dane dotyczące produkcji gazu i ropy. Dla gazu odnotowano wzrost o 42\%, z 468 do 664 Mtoe między rokiem 2005 i 2013. Przed rewolucją łupkową, trend produkcji gazu był nieregularny, ale głównie spadkowy - z najwyższym poziomem wynoszącym 560 Mtoe (na początku lat siedemdziesiątych XX w.). Wpływ rewolucji na ropę stał się widoczny dopiero w 2008 roku - o trzy lata później niż w przypadku gazu. W ciagu 4 lat od 2008 do 2013 roku, produkcja ropy gwałtownie wzrosła o 64\%; z $305 \mathrm{mln}$ ton do $499 \mathrm{mln}$ ton. Ponownie, przydatne może okazać się długofalowe spojrzenie na historię produkcji. W ciągu ostatnich 40 lat miał miejsce niemal ciągły spadek wielkości produkcji. Od szczytu w 1970 roku na poziomie 534 Mtoe, produkcja spadła o $43 \%$ do 305 Mtoe w przełomowym roku 2008.

Instytucje takie jak EIA i IHS (EIA 2013a; IHS 2012) twierdza, że dominującą część wzrostu produkcji gazu i ropy, pokazane na wykresie, można przypisać eksploatacji zasobów z formacji łupkowych. Dostępność łupków i przełomowe rozwiązania technologiczne, które obniżyły koszty, miały fundamentalne znaczenie dla szybko rosnącej produkcji, 


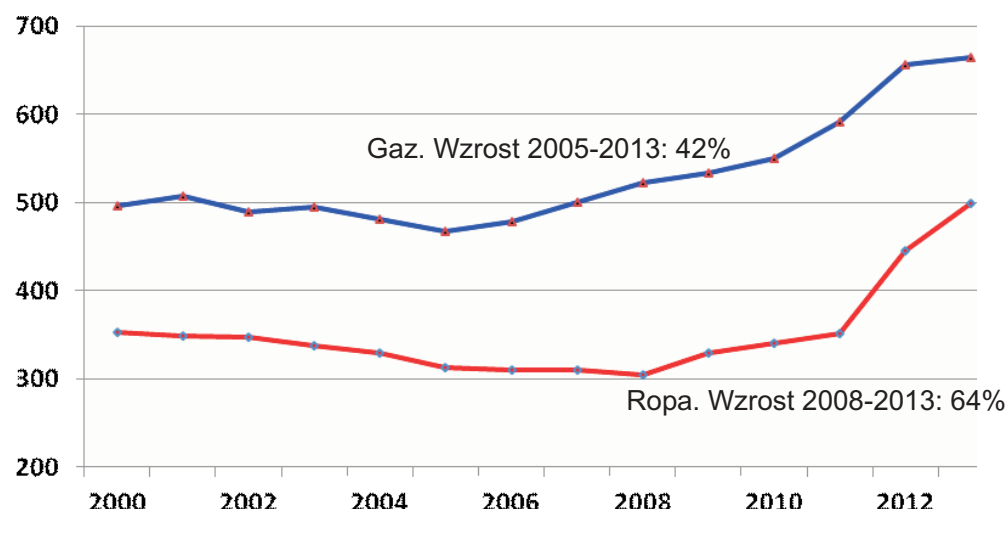

Rys. 1. Produkcja gazu ziemnego i ropy w USA [Mtoe]

Źródło: EIA (dane za rok 2013 na podstawie prognozy EIA z października 2013)

Fig. 1. US natural gas and oil production [Mtoe]

a rozwój ten został przyśpieszony dzięki gwałtownemu wzrostowi cen gazu w USA w roku 2000 i równie silnemu wzrostowi cen ropy naftowej cztery lata później.

Postęp technologiczny, który w ciągu ostatnich dziesięciu lat zapewnił ekonomiczną opłacalność eksploatacji wybranych zasobów gazu łupkowego, zdecydowanie zwiększył zainteresowanie poszukiwaniem tego surowca i ocenąjego potencjału gospodarczego. Przed rewolucją łupkową wiedza na temat zasobów węglowodorów w łupkach była dość mglista. W ciągu ostatnich dziesięciu lat wspomniana wiedza powiększyła się w zawrotnym tempie, co zmieniło opinię na temat stanu zasobów gazu w USA, choć w dalszym ciągu podawane wielkości budzą szereg poważnych wątpliwości. W roku 2003, amerykańska Krajowa Rada ds. Ropy Naftowej (National Petroleum Council) oszacowała technicznie wydobywalne zasoby gazu w formacjach łupkowych w USA na 990 Mtoe. W 2009 roku amerykański Komitet Potencjału Gazowego (Potential Gas Committee) podniósł tę liczbę do poziomu 17680 Mtoe (Medlock 2012), podczas gdy ocena tej instytucji z grudnia 2012 roku to już 27900 Mtoe - co stanowi ponad połowę całości krajowych zasobów gazu (PGC 2013). Dane o zasobach można porównać z wielkością całkowitej produkcji gazu w USA, która w 2012 roku wyniosła 633 Mtoe, z czego z formacji łupkowych wydobyto około 440 Mtoe (EIA 2013a).

W roku 2010 roku produkcja gazu z łupków była praktycznie wyłącznie amerykańską specjalnością. Udział tego kraju w światowej produkcji był bliski 99\% (IEA 2011a). Już w roku 2008 gaz z łupków stanowił ponad połowę całkowitej produkcji gazu ziemnego Stanów Zjednoczonych, przy średnich kosztach nie wyższych niż dla gazu konwencjonalnego (IEA 2009). Nowsze szacunki określają te koszty w zakresie pomiędzy 3-7 USD/MBTU, co uznawane jest za korzystne w porównaniu do większości źródeł gazu na świecie (IEA 2011b). Faktycznie, postęp technologiczny zmniejszył koszty produkcji gazu z łupków do poziomu, przy którym - w niektórych przypadkach - są one niższe niż gazu konwencjonalnego. Medlock (2012) podaje, że jedna czwarta zasobów gazu w formacjach łupkowych 
USA zidentyfikowanych w 2009 (4420 Mtoe z ogółu 17680 Mtoe) może zostać wydobyta przy całkowitych kosztach poniżej 3 USD/MBtu. Koszty zależą przede wszystkim od dostępności płynów szczelinujących, ponieważ dochody z ich sprzedaży są zaliczane do kosztów wydobycia gazu.

Wydobycie ropy z łupków w USA na dużą skalę ma za sobą jeszcze krótszą historię niż wydobycie gazu z łupków, stąd wiedza na temat wydobywalnych zasobów tego surowca jest bardzo niekompletna. Analiza opracowana przez Energy Information Administration w odniesieniu do roku 2009 (EIA 2011a) określiła je na 3,3 mld ton, ale do roku 2010 wielkość ta została skorygowana do poziomu 4,6 mld ton (IEA 2012a), co stanowiło więcej niż $25 \%$ potwierdzonych krajowych zasobów wydobywalnych. Amerykańska produkcja ropy z łupków spektakularnie podwoiła się z poziomu $25 \mathrm{mln}$ ton w 2010 roku do około 50 mln ton w 2012 roku (IEA 2012a), a w roku 2013 jeszcze znacząco wzrosła. Koszty eksploatacji ropy z łupków są zazwyczaj niższe niż w przypadku kanadyjskich piasków roponośnych czy brazylijskiej głęboko zalegającej ropy, których szacowane średnie koszty produkcji wynoszą około 70 USD za baryłkę (GEA 2012). Wydobycie ropy naftowej z łupków w Ameryce Północnej staje się opłacalne przy cenach ropy nieco poniżej 50 USD za baryłkę (IEA 2011a). Poza USA produkcja ropy z łupków jest, jak do tej pory, pomijalna.

\section{Wplyw na USA i międzynarodowe rynki energii}

Wysokie koszty transportu wraz z niedostatkami infrastruktury transportowej oraz restrykcyjna polityka handlowa tłumaczą istotne różnice cen gazu na rynkach regionalnych. Ceny gazu ziemnego od zawsze były zróżnicowane w zależności od lokalizacji rynku; kompleksowe omówienie różnych struktur rynków gospodarczych, które panowały na rynkach regionalnych, można znaleźć w opracowaniu Dahl'a (2004). Ameryka Północna jest jednym z najbardziej konkurencyjnych regionalnych rynków gazu. Większość gazu ziemnego jest sprzedawana na podstawie porozumień cenowych, które opierają się na cenie gazu ziemnego notowanej w Henry Hub (HH), Luizjana. Europejskie ceny gazu ziemnego w dużym stopniu opierają się na cenach produktów ropopochodnych, inaczej niż w Ameryce Północnej, gdzie już od lat osiemdziesiątych dwudziestego wieku dominuje wycena typu gas-on-gas (oparta na równowadze podaży z popytem). Istnieje wprawdzie zauważalna w Europie tendencja do odchodzenia od wyceny na bazie ropy, ale postępy w kierunku systemu opartego na ośrodkach sprzedaży i wyceny typu gas-on-gas są wciąż niewielkie. Począwszy od roku 2010, LNG od różnych producentów pojawił się także na rynku azjatyckim. Zapotrzebowanie jest większe niż tylko terytorium Japonii, będące niegdyś dominującym rynkiem, i dotyczy Tajwanu, Korei Południowej i Chin, a prace nad projektami tego typu są w toku w wielu innych krajach regionu. Wycena gazu ziemnego w Azji była historycznie oparta o ceny ropy naftowej, a rozwiązania alternatywne wprowadzono dopiero od niedawna. 
Rysunek 2 pokazuje, że różnica dzieląca rynek amerykański od pozostałych gwałtownie wzrosła w roku 2009, wraz ze zwiększeniem wydobycia z formacji łupkowych w USA. Rysunek przedstawia ceny w Stanach Zjednoczonych w latach 2009-2013 znacznie poniżej poziomu z lat 2003-2008, a więc z okresu poprzedzającego wpływ rosnącej podaży gazu na ceny.

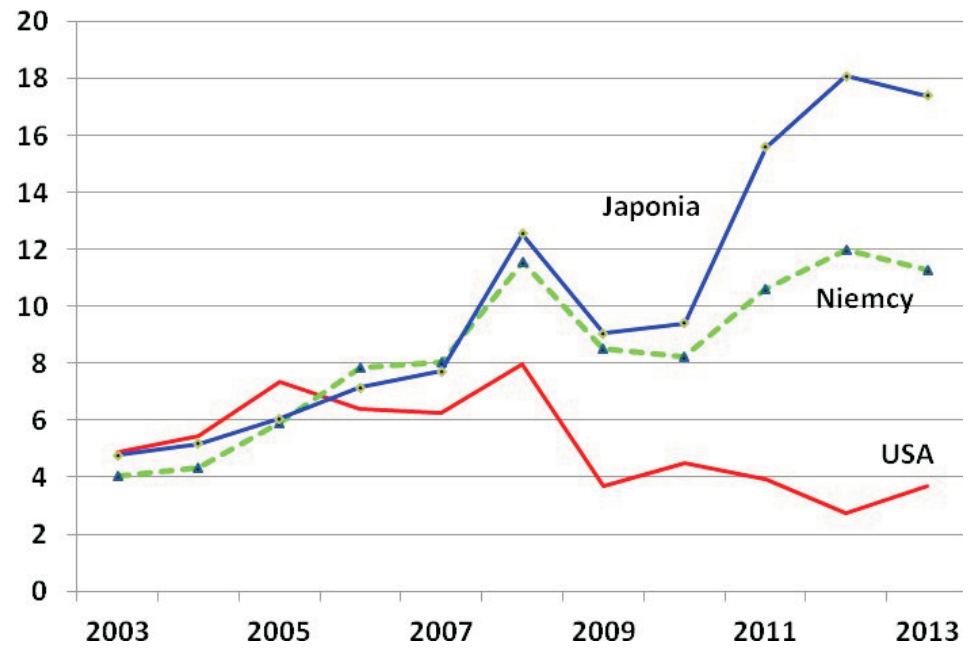

Rys. 2. Ceny gazu ziemnego [USD/MBTU]. Rok 2013 - od stycznia do września Japonia: ceny kontraktów długoterminowych na import LNG z Indonezji, Niemcy: ceny kontraktów długoterminowych na import z Rosji, USA: średnie ceny ex work Źródła: BP; IMF

Fig. 2. Natural gas prices [USD/MBTU]. 2013 - January to September

Japan: long term LNG contract prices for imports from Indonesia, Germany: long term contract prices for imports from Russia, USA: Average wellhead prices

Jak już wspomniano, Energy Information Administration oceniła, że bogate zasoby gazu mogą być wydobywane w USA z formacji łupkowych przy kosztach w przedziale od 3 do 7 USD (IEA 2011b). Taki wniosek pozwalał z dużą dozą prawdopodobieństwa spodziewać się zmniejszenia lub przynajmniej zastoju $\mathrm{w}$ produkcji gazu z łupków przy cenach na poziomie 4 USD lub niższych, jak to się stało począwszy od 2009 roku. Rzeczywiście, doszło do zdecydowanej redukcji liczby platform wiertniczych, głównie tych przeznaczonych do eksploatacji gazu z łupków, z około 1500 w 2008 roku do mniej niż 900 w 2011 roku, jako że wiercenia skupiły się na poszukiwaniu ropy z łupków. W tym samym czasie liczba tych ostatnich wzrosła z 400 do 900 (IEA 2011a), ponieważ rewolucja łupkowa nie wpłynęła na ceny ropy naftowej. Co zaskakujące, zmniejszona liczba urządzeń wiertniczych przeznaczonych do poszukiwań gazu nie miała znaczącego wpływu na wzrost produkcji. Postępujący w zawrotnym tempie rozwój technologiczny, obniżający koszty produkcji gazu łupkowego, znacznie zwiększający efektywność operacji wiertniczych, stanowi wiarygodne wyjaśnienie tej zaskakującej obserwacji (EPRINC 2011). Całkowita produkcja gazu w USA 
w przeliczeniu na odwiert w latach 2008-2012 wzrosła ponad trzykrotnie (EPRINC 2013). Przejście do eksploatacji bogatszych złóż, które pozwalają na większą wydajność oraz transakcje hedgingowe zabezpieczające wcześniejsze wysokie ceny na kilka lat naprzód stanowią dodatkowe wyjaśnienie uzyskiwanych poziomów wydobycia w obliczu spadających cen gazu.

Dla użytkowników gazu w USA tani gaz był dobrodziejstwem. Dla przykładu, rentowność przemysłu petrochemicznego w Stanach Zjednoczonych znacznie wzrosła, ku rozczarowaniu europejskich i japońskich konkurentów. W energetyce nastapiło jednoznaczne odejście od węgla na rzecz gazu, co ograniczyło emisje $\mathrm{CO}_{2}$ w USA o ponad $10 \%$ w latach 2007-2012 (Hasset i Mathur 2013), a zarazem przyczyniło się do powstania nadwyżki podaży węgla. Rozwój wydobycia gazu z łupków spowodował kilka zmian na rynku węgla w Stanach Zjednoczonych. W latach 2007-2012 ceny węgla spadły i nastąił spadek produkcji o $11 \%$, tj. o 130 milionów ton. W tym samym czasie eksport zwiększył się ponad dwukrotnie do poziomu $126 \mathrm{mln}$ ton (EIA 2013b), trafiając głównie do europejskich konsumentów (IEA 2012a). W obliczu decyzji o likwidacji energetyki jądrowej w Niemczech, popyt na węgiel zwiększył się zwłaszcza w tym kraju.

Zwiększenie krajowych dostaw gazu zdecydowanie zmniejszyło zapotrzebowanie importowe USA na ten surowiec W latach 2007-2012 całkowita wielkość importu spadła o $32 \%$ do poziomu 80 Mtoe, podczas gdy import LNG zmniejszył się o $78 \%$ do 4,4 Mtoe (BP Annual), przyczyniając się do obniżenia wykorzystania wielu istniejących instalacji do importu LNG, a w konsekwencji ich konwersji na instalacje eksportowe. Rozważana jest sprzedaż znacznych ilości LNG za granicę. Do roku 2012 roku rozpoczęto planowanie ośmiu projektów służących eksportowi LNG o łącznej wydajności 150 Mtoe (Stevens 2012), których realizacja miałaby się rozpocząć około roku 2015 (IEA 2012a). Przy pełnym wdrożeniu będzie to oznaczać podwyższenie o około 50\% możliwości eksportowych LNG w porównaniu z 2012 rokiem (BP Annual). Licencję na eksport przyznano do tej pory czterem z projektów (na 60 Mtoe rocznie), przy czym jeszcze kilka ma szansę do nich dołączyć (Abiteboul 2012; Platts 2013). Opozycja wewnętrzna wobec eksportu LNG używała argumentu, że eksport podniesie ceny krajowe, ale oszacowany wzrost cen - w granicach $2-11 \%$ przy realistycznych założeniach eksportowych (Ebinger i Avasarala 2013) - nie powinien stanowić zagrożenia dla odbiorców gazu. W badaniu przeprowadzonym dla Departamentu Energii Stanów Zjednoczonych przez NERA Economic Consulting (2012) stwierdza się, że eksport LNG przyniesie w sumie korzyści ekonomiczne netto dla gospodarki kraju.

Załamanie amerykańskiego importu LNG przełożyło się na obniżkę cen w Europie i Azji, jako że dostawy LNG przeznaczone dla USA musiały zostać przekierowane do innych miejsc. Wpływ ten został chwilowo zmniejszony wzrostem popytu w następstwie japońskiej katastrofy nuklearnej w Fukushimie. Rosyjski monopolista eksportu gazu, Gazprom, którego sprzedaż jest zdominowana przez długoterminowe kontrakty z cenami ściśle związanymi z wysoką ceną ropy, został zmuszony do bolesnych korekt ze względu na znacznie niższe ceny spot na rynku europejskim. Klienci wykorzystali istniejące elastyczności umów zamawiając minimalne ilości i żądając pełnej renegocjacji warunków wraz z wygasaniem 
umów. Aby zabezpieczyć swój rynek w Polsce, Gazprom w swojej umowie z Polską w 2012 roku zaakceptował obniżenie cen o 15\%. Boom gazu z łupków stanowi cios dla perspektywy wzrostu produkcji tej firmy, jej możliwości kształtowania cen energii i przychodów (Vihma 2013). Wizja pojawiających się nadwyżek dostaw gazu wraz z normalizacją sytuacji w Japonii oraz rozpoczęciem przez USA eksportu LNG wiąże się z redukcją cen gazu na wszystkich rynkach regionalnych, przy jednoczesnym zwiększeniu roli cen spot (Robinson i Qinhua 2013). Warto jednak zauważyć, że ceny w regionie Azji i Pacyfiku są zablokowane przez kontrakty długoterminowe i odejście od ropy naftowej może być czasochłonne i skomplikowane.

Następstwa amerykańskiej rewolucji łupkowej dla rynków i konsumentów ropy naftowej są jak dotąd o wiele mniej poważne. Rynek ropy jest prawdziwie globalny, więc wpływ zmian, jakie zaszły w Stanach Zjednoczonych - na przykład w zakresie cen - rozmywa się. Główną zmianą związaną z rynkiem ropy naftowej jest spadek zapotrzebowania importowego w USA. Abstrahując od handlu gotowymi produktami i skupiając się na nierafinowanej ropie naftowej można zauważyć, że jej zużycie w USA w 2008 roku przekroczyło produkcję krajową o $570 \mathrm{mln}$ ton. Tyle ropy sprowadzono z zagranicy. Do roku 2012, różnica ta skurczyła się do 470 milionów ton, głównie ze względu na zwiększenie produkcji z krajowych łupków. Trzeba jednak zaznaczyć, że we wspomnianym 2012 roku Stany Zjednoczone były wciąż dalekie od samowystarczalności, przy czym ocenia się, że doprowadzenie do niej w dającej się przewidzieć przyszłości - nawet przy kontynuacji ekspansji produkcji ropy z łupków - jest mało prawdopodobne (FT Alphaville 2012). Zmniejszające się zapotrzebowanie importowe USA dało impuls do handlu $\mathrm{z}$ wykorzystaniem zbiornikowców, zwiększając średnią odległość pokonywaną przez ropę w handlu międzynarodowym. Wraz ze spadkiem importu do USA, krótkie dystanse służące do dostarczania wenezuelskiej i angolskiej ropy do wschodnich wybrzeży USA zamieniono na kierunki azjatyckie (FT 2013a).

Eksploatacja zasobów ropy łupkowej w USA staje się opłacalna ekonomicznie przy cenach ropy w granicach 45-70 USD, a przy łupkach wyższej jakości, takich jak Bakken i Eagleford, bliżej tej dolnej wartości (Rystad Energy 2012). Jest to nieco poniżej poziomu cen kanadyjskich piasków roponośnych i znacznie poniżej cen dla ropy naftowej w latach 2011-2013. Kanadyjski Instytut Badań nad Energią (The Canadian Energy Research Institute) przeprowadził badania na temat kosztów eksploatacji piasków roponośnych, wyznaczając próg rentowności na poziomie 45-90 USD/boe ( 1 boe $=0,146$ toe) (CERI 2012). Ropa z łupków jest znacznie tańsza w produkcji, wahając się w granicach 10-40 USD/boe (IEA 2012b).

\section{Rewolucja łupkowa i jej ogólne korzyści dla gospodarki USA}

Korzyści można podzielić na te generowane w sektorze ropy i gazu oraz te wynikające z niższych cen gazu dla reszty gospodarki. Istotnym czynnikiem przy ocenie obydwu 
przypadków jest istnienie od wielu lat znacznych niewykorzystanych mocy produkcyjnych w gospodarce amerykańskiej, tak na rynkach pracy, jak również w obiektach przemysłowych. Ta nadwyżka mocy produkcyjnych może być uznana za wolne zasoby, jeśli tylko uda się je uaktywnić. Powyższe wnioski opierają się głównie na ostatnich badaniach (IHS 2012) dotyczących ustalenia wielkości zysków w sektorze ropy i gazu za 2012 rok. Usługi doradcze IHS, koncentrujące się na ekonomice energetyki, są znane od wielu lat. O ile w dalszej części nie powołano się na inne źródła, to właśnie ustalenia IHS są źródłem prezentowanych danych.

IHS szacuje całkowite inwestycje w gaz i ropę z łupków w 2012 roku na poziomie 87 mld USD (0,6\% PKB Stanów Zjednoczonych, szacowanego na 15700 dolarów mld w tym samym roku), z czego 47 mld USD jest przeznaczanych na gaz. Inwestycje te, wraz z działalnością związaną z produkcją z łupków, dają ogólne bezpośrednie zatrudnienie na poziomie 360000 osób. Oznacza to wzrost do 1,75 mln (co stanowi 1,3\% całkowitego zatrudnienia w USA wynoszącego $135 \mathrm{mln}$ ), jeśli weźmie się pod uwagę pośrednie oraz indukowane efekty zatrudnienia, z czego połowa odnosi się do gazu z łupków. Przychody osób zatrudnionych zostały ocenione na 125 mld USD, przy znacznie większej wartości dodanej wynoszącej 240 mld USD, co uwzględnia podwyższoną kapitałochłonność tej działalności. Jeśli chodzi o wielkość wartości dodanej, wkład sektora łupkowego do PKB stanowił około $1,5 \%$ - co jest bardzo imponującą liczbą. Biorąc pod uwagę względną samowystarczalność USA w dziedzinie technologii i innych nakładów, ucieczki za granicę byłyby ograniczone i większość korzyści pozostałaby w kraju.

Całkowite dochody podatkowe $\mathrm{z}$ eksploatacji łupków w formie podatku od dochodu pracowników, podatku od zysków przedsiębiorstw i opłat eksploatacyjnych wynoszą 62 mld USD. Aby docenić znaczenie dochodów podatkowych trzeba zauważyć, że dochody przepadające z tych tytułów dla Rządu Federalnego, tj. 31 mld USD, wystarczyłyby na sfinansowanie $80 \%$ połączonych budżetów Departamentu Spraw Wewnętrznych, Departamentu Handlu i NASA.

Są to skutki eksploatacji łupków w 2012 roku, ale IHS przewiduje, że wzmiankowane korzyści będą się utrzymywać, a nawet rosnąć z roku na rok, wraz z rozwojem eksploatacji łupków. Do 2035 roku inwestycje wyrażone w cenach stałych wzrosną do poziomu 350 mld USD, a dochody z podatków - do 125 mld USD, podczas gdy zatrudnienie w sektorze wzrośnie do poziomu 3,5 miliona osób.

Jak odnotowano wcześniej, niższe ceny gazu znacznie wzmocniły konkurencyjność przemysłu petrochemicznego USA, promując ekspansję tego sektora. Jednak dobra koniunktura wynikająca $\mathrm{z}$ niskich cen gazu jest odczuwalna także poza przemysłem petrochemicznym. Producenci nawozów i stali, użytkujący duże ilości gazu ziemnego, w równym stopniu korzystaja z tej sytuacji. W szerszym ujęciu, Dow Chemicals odnotował w 2012 roku, że spora grupa amerykańskich producentów zapowiedziała 90 mld USD nowych inwestycji w USA, aby wykorzystać tani rodzimy gaz ziemny (Vihma 2013). 


\section{Perspektywy dla USA i spodziewane implikacje}

Na podstawie danych zawartych w badaniu IHS przedstawionym w poprzedniej części, w najbliższych dwóch dekadach można spodziewać się w USA eksploatacji ropy i gazu z łupków na szeroką skalę. Pogląd ten w pewnym stopniu potwierdzają najnowsze prognozy formułowane przez Departament Energii Stanów Zjednoczonych oraz Międzynarodową Agencję Energetyczną.

Na fali rewolucji łupkowej, USA wyprzedziły Rosję w 2009 roku i stały się największym na świecie producentem gazu. Jak wspomniano, produkcja gazu w USA wzrosła o $42 \%$ w ciągu ośmiu lat między rokiem 2005 i 2013 do poziomu 664 Mtoe. Oczekuje się, że produkcja rosyjska wzrośnie o mniej niż 5\% w latach 2005-2015, aby ostatecznie osiagnąć poziom 550 Mtoe. IEA oraz EIA przewidują dalszy rozwój wydobycia gazu w USA, choć w znacznie wolniejszym tempie niż w niedawnej przeszłości. IEA (2012a) przewiduje, że do 2035 roku wydobycie gazu w USA osiagnie poziom 720 Mtoe, to jest $14 \%$ powyżej tego z 2012 roku. Prognozy EIA zakładają 815 Mtoe w 2035 roku (EIA 2013a), a więc wzrost o kolejne $30 \% \mathrm{w}$ ciągu 23 lat. Obie agencje upatrują główną przyczynę dla zapowiadanych wzrostów właśnie w związku z wydobyciem z formacji łupkowych. Obie także przewidują rozpoczęcie amerykańskiego eksportu LNG przed 2020 rokiem.

Obie instytucje przewidują również wpływ rewolucji łupkowej na ropę naftową, przynajmniej do 2020 roku, ale tak jak w przypadku gazu, w znacznie wolniejszym tempie niż w ostatnich latach. Do 2020 roku Stany Zjednoczone mają zostać największym na świecie producentem przy wydobyciu na poziomie około $530 \mathrm{Mt}$, ale - zaskakująco - moment ten ma też wyznaczyć schyłek rewolucji związanej z ropą z łupków; potem nastąpi długotrwały spadek wydobycia aż do 2035 roku (koniec okresu prognozy). USA mają nie osiagnąć samowystarczalności pod względem produkcji ropy naftowej, wciąż importując ten surowiec, co najmniej do 2035 roku. Prognozy wzrostu wydobycia EIA są zestawione w tabeli 1. Kontrast pomiędzy rzeczywistymi a prognozowanymi wartościami jest bardzo wyraźny.

Tabela 1. Wzrost wydobycia gazu ziemnego i ropy naftowej w USA - wartości rzeczywiste (2008-2012) i prognozy EIA, procent na rok

Table 1. US gas and oil output growth - actual (2008-2012) and EIA projections, percent per year

\begin{tabular}{|c|c|c|c|c|}
\hline Wyszczególnienie & $2008-2012$ & $2012-2020$ & $2020-2030$ & 2030-2035 \\
\hline Gaz ziemny & 4,9 & 1,1 & 1,1 & 1,0 \\
\hline Ropa naftowa & 7,4 & 3,4 & $-1,4$ & 0 \\
\hline
\end{tabular}

Źródło: EIA 2013a

IEA nie przedstawia prognoz cenowych, ale EIA przewiduje do 2035 roku wzrost cen do poziomu $6,32 \mathrm{USD} / \mathrm{MBtu}$ dla gazu $(+59 \% \mathrm{w}$ stosunku do $2011 \mathrm{roku})$ oraz do poziomu 145 USD/baryłkę dla ropy naftowej (+31\% od 2011 roku), w cenach stałych z 2011 roku. 
Zakładany niewielki wzrost wydobycia lub jego brak oraz rosnące ceny wydają się zaskakujące biorąc pod uwagę doświadczenia z niedawnej przeszłości, kiedy technologia eksploatacji zasobów łupkowych była wielokrotnie modernizowana, wydajność wzrastała znacznie szybciej od oczekiwań, a koszty i ceny spadały. Tymczasowy charakter rewolucji odzwierciedlony $\mathrm{w}$ prognozach stoi $\mathrm{w}$ sprzeczności $\mathrm{z}$ już udokumentowanym bogactwem zasobów łupkowych Stanów Zjednoczonych, a tym bardziej z obiecującymi odkryciami ostatnich prac poszukiwawczych. Dynamika postępu technologicznego i ilości wydobywalnych zasobów są zdumiewające: w latach 2008-2013 oceniana wielkość złoża ropy w łupkach Bakken (USA) wzrosła ponad pięciokrotnie do 2,5 mld ton (IEA 2013). Stąd też można podważyć oficjalne prognozy i zasugerować bardziej optymistyczne spojrzenie.

Niezależnie od tego, która prognoza okaże się prawidłowa, jest oczywistym, że przewodnictwo Stanów Zjednoczonych w rewolucji łupkowej sprawi, że kraj ten będzie w mniejszym stopniu zależny od zagranicznych dostaw paliw kopalnych, co pozwoli mu rozwinąć działania na rzecz zaspokojenia krajowych potrzeb konsumpcyjnych.

\section{Czy rewolucja lupkowa rozprzestrzeni się na cały świat?}

Najpewniej tak, bo możliwości istnienia zasobów są duże i potencjalnie można rozpowszechnić istniejące technologie na resztę świata (Fattouh 2013), choć niewiele można powiedzieć o jakości zasobów w porównaniu z tymi w USA. Kluczowa jest odpowiedź na pytanie, kiedy rewolucja ogarnie inne regiony świata. Artykuł próbuje rozwiązać tę kwestię poprzez przedstawienie przyczyn, dla których USA są liderem rewolucji łupkowej oraz poprzez odpowiedź na pytanie, jak długo ta sytuacja może potrwać.

Krótka lista okoliczności wystarczy, aby wyjaśnić przyczyny, dla których USA zdobyło i utrzymuje pozycję lidera $\mathrm{w}$ tej dziedzinie. Pierwsza $\mathrm{z}$ nich to oczywiście bogactwo zasobów, choć wiele krajów podziela tę cechę ze Stanami Zjednoczonymi. Długa historia eksploatacji gazu na dużą skalę zagwarantowała z kolei zarówno zaawansowanie technologiczne, jak i infrastrukturę odpowiednią do eksploatacji gazu konwencjonalnego. Oba te elementy mogą być łatwo zaadaptowane na potrzeby gazu z łupków. Znana na całym świecie infrastruktura instytucjonalna, konieczna do wspierania innowacyjnych działań na arenie międzynarodowej, została z łatwością dostosowana dla potrzeb rozwoju gazu z łupków. Niska gęstość zaludnienia pozwoliła zminimalizować społeczny brak akceptacji związany z obawami o środowisko naturalne. Inną sprzyjającą okolicznością jest to, że ustawodawstwo USA przyznaje właścicielom gruntu prawo własności do tego, co znajduje się pod ziemią, która to zasada nie jest stosowana przez wiele innych krajów. Prawodawstwo Stanów Zjednoczonych unika problemów związanych z prawem użytkowania gruntów, ponieważ to właściciel czerpie korzyści z opłat eksploatacyjnych. Długa tradycja małych, odważnych przedsiębiorstw poszukiwawczych w USA pomogła przyspieszyć proces rewolucji łupkowej. Biurokratyczne giganty energetyczne początkowo pozostawały sceptyczne, jednak 
skwapliwie wkroczyły do gry, gdy tylko firmy poszukiwawcze potwierdziły potencjał geologiczny i gospodarczy oraz zaoferowały sprzedaż odkrytych złóż. Wszystkie te czynniki pozwalają zrozumieć, dlaczego Stany Zjednoczone przejęły inicjatywę w rewolucji łupkowej i dlaczego większość innych krajów pozostaje daleko w tyle.

Globalne zasoby gazu w formacjach łupkowych są słabo rozpoznane, podczas gdy wiedza na temat zasobów ropy w łupkach jest jeszcze mniejsza. Badanie zlecone przez EIA i opublikowane w kwietniu 2011 roku (EIA 2011b), jednak przy użyciu danych nie nowszych niż te dostępne w 2009 roku, określa potencjał technicznie wydobywalnych zasobów na poziomie 171600 Mtoe, z czego 13\% znajduje się w Stanach Zjednoczonych. Liczba ta znajduje się w tym samym przedziale co światowe potwierdzone zasoby wydobywalne gazu konwencjonalnego, wynoszące 190000 Mtoe i stanowi 57-krotność rocznego światowego wydobycia gazu w 2012 roku, tj. 3033 Mtoe (BP Annual). Ponieważ badanie nie obejmuje kilku ważnych regionów - zwłaszcza Rosji, Bliskiego Wschodu i Azji Południowo-Wschodniej - jego ustalenia muszą być znacznie poniżej rzeczywistego poziomu globalnego.

Bardziej aktualna ocena, opublikowana w czerwcu 2013 roku (EIA 2013c), szacuje globalne zasoby gazu łupkowego na 189800 Mtoe, to jest o około $10 \%$ więcej w porównaniu z wielkościami podanymi w 2011 roku. Liczba uwzględnianych krajów wzrosła z 32 do 41 . Potencjał wydobywalnych zasobów gazu w łupkach jest w wielu rejonach świata: Chiny posiadają 15\%, Argentyna 11\%, Algieria 10\%, Stany Zjednoczone 9\%, Kanada 8\%, Meksyk 7\%, Australia 6\%, Republika Południowej Afryki 5\%, a Rosja 4\% zasobów. Brazylia, Wenezuela, Polska, Francja i Libia znajdują się wśród pozostałych krajów o znaczącym potencjale zasobowym.

IEA (2012a) szacuje globalne zasoby gazu w formacjach łupkowych na 295000 Mtoe i 235000 Mtoe z wyłączeniem Ameryki Północnej, jednak zastosowany podział dotyczy poszczególnych kontynentów, bez danych dotyczących poszczególnych krajów. Wyższe wielkości podawane przez IEA wynikają z objęcia badaniami szerszego zasięgu geograficznego.

Który spośród posiadaczy zasobów gazu w łupkach wymienionych w badaniach EIA, wyłączając USA, może przejąć inicjatywę w zakresie wykorzystania tych zasobów i kiedy ta rewolucja może się zacząć? Analizując tę kwestię EIA wskazuje na problem rozbudowy niezbędnej infrastruktury jako najpoważniejszy czynnik stanowiący przyczynę opóźnień. Jeżeli infrastruktura jest opracowywana od podstaw, może to zająć nawet 10 lat. Stąd też pozycję lidera mogą zająć tylko te kraje, które już są znaczącymi producentami gazu konwencjonalnego, ponieważ istniejąca infrastruktura może być łatwo dostosowana do eksploatacji gazu łupkowego.

Kanada, z jej długim doświadczeniem w eksploatacji ropy i gazu, ma również strategiczną przewagę w rozwoju łupków. Kanadyjska produkcja gazu ziemnego zajmuje obecnie trzecie miejsce na świecie, przy czym gaz z łupków stale zwiększa swój udział. Kanadyjskie Stowarzyszenie Producentów Ropy Naftowej (CAPP 2013) spodziewa się, że gaz z łupków z zachodniej części Kanady stanie się dominującym źródłem krajowych dostaw gazu po 
2020 roku. Według Bernstein Research także Australia może stać się jednym z największych - spoza Ameryki Północnej - krajów eksploatujących łupki, a to ze względu na podobieństwo warunków geologicznych w obu regionach (SPE News 2013).

Chiny, posiadające imponujące bogactwo zasobów, wydobywające znaczne ilości gazu konwencjonalnego, pomimo pozytywnego nastawienia szeregu instytucji nie spodziewają się rewolucji łupkowej na pełną skalę przed 2020 rokiem (Fan Gao 2012). Niemniej jednak, do 2035 roku gaz z łupków ma stanowić 70\% całkowitego wydobycia gazu (IEA 2012a). Niedobory wody, obecnie niezbędnej do szczelinowania, stanowią jednak wyzwanie tak w Chinach, jak i w Australii.

W Argentynie, kraju którego baza zasobowa jest niemal równa tej w USA, postęp został zahamowany z przyczyn związanych z sytuacją polityczną tego kraju. Przykładowo, niepewność wśród inwestorów zagranicznych budzi niedawne przejęcie przez rząd hiszpańskiego przedsiębiorstwa Repsol. Tym niemniej, amerykański Chevron osiagnął niedawno porozumienie dotyczące zainwestowania 1,24 mld USD - wraz z państwowym przedsiębiorstwem energetycznym YPF - w hupki w formacji Vaca Muerta (FT 2013b).

Postęp w Europie jest niepewny, przede wszystkim ze względów środowiskowych. Francja zakazała działań związanych z gazem łupkowym, prawdopodobnie w celu uniknięcia zmarnowania kapitału zainwestowanego w sektor jądrowy. Bułgaria również wprowadziła zakaz wierceń za gazem z łupków, być może wskutek wysiłków Rosji na rzecz możliwości utrzymania eksportu gazu w tym kierunku. Wysoka gęstość zaludnienia w Europie oraz wrażliwość na środowisko naturalne mogą łatwo uczynić ten kontynent maruderem w rewolucji związanej z gazem z łupków. Co więcej, w większości krajów europejskich prawo własności do zasobów znajdujących się pod powierzchnią należy do państwa, co zwiększa niechęć właścicieli gruntu do wyrażenia aprobaty dla przeprowadzania wierceń. Wreszcie, wiele europejskich firm jest własnością państwa, a tym samym mają odmienne cele w porównaniu do małych, specjalistycznych i niezależnych firm działających w USA. Niemniej jednak, biorąc pod uwagę korzyści odniesione przez USA (patrz rozdział piąty), kwestią otwartą jest, czy Europa będzie w stanie oprzeć się tej pokusie na dłuższą metę.

Polska, z największym potencjałem zasobowym gazu w formacjach łupkowych w Europie (EIA 2013c), dąży do rozwoju tego sektora z całą siłą, mimo niedawnego wycofania się spółki ExxonMobil (patrz następny rozdział). Polska jest silnie motywowana przez swoją wysoką zależność od importu gazu od sąsiada skłonnego do wykorzystywania dostaw surowca do celów politycznych. Według Ministerstwa Skarbu Państwa (Polish Ministry of Treasury 2013), bieżące poszukiwania gazu z łupków stanowią jedno z kluczowych działań inwestycyjnych w Polsce, w którym uczestniczy szereg podmiotów, zarówno polskich, jak i zagranicznych. W końcowej fazie przygotowań jest (podobno) atrakcyjny pakiet fiskalny, jednak szczegóły dotyczące zasad ochrony środowiska, które mają być stosowane do gazu z formacji łupkowych wciąż nie są precyzyjnie sformułowane. Tym niemniej, 2015 rok jest postrzegany jako wiarygodny termin rozpoczęcia wydobycia gazu z łupków. 
Jak odnotowano we wcześniejszym rozdziale, Rosja, posiadająca 22\% światowych zasobów konwencjonalnego gazu i $21 \%$ udział w światowym eksporcie tego surowca w 2011 roku, czuła się zagrożona przez amerykańską rewolucję łupkową. Według nieoficjalnych doniesień, Rosja uporczywie próbowała opóźnić postęp rewolucji poprzez finansowanie grup ekologicznych lobbujących przeciwko gazowi z łupków. Panuje też przekonanie, że Rosja wykorzystała własne zasoby energetyczne, aby odwieść międzynarodowe firmy energetyczne od angażowania się w rewolucję lupkową. Wycofanie się spółki ExxonMobil z Polski w 2012 roku było postrzegane jako warunek konieczny dla zawarcia przez nią lukratywnej umowy z Rosnieft, dotyczącej rozpoznania i eksploatacji złóż Arktyki (Tucker 2012). Ogłoszenie w 2010 roku Globalnej Inicjatywy Gazu z Łupków (Global Shale Gas Initiative) przez Departament Stanu USA (EIA 2011b), może być postrzegane jako polityczna odpowiedź na spowalniające działania Rosji oraz jako dążenie do zmniejszenia światowej zależności od rosyjskiego gazu. Inicjatywa ma pomóc potencjalnym producentom gazu z lupków przy ocenie zasobów, transferze technologii i doradzać jak tworzyć infrastrukturę instytucjonalną.

Eksploatacja zasobów ropy z lupków poza USA będzie prawdopodobnie mniejsza niż w przypadku gazu łupkowego. Badanie zlecone przez niemiecki Federalny Instytut Nauk o Ziemi i Zasobach Naturalnych (DERA 2012) stwierdza, że poszukiwania tych zasobów ledwie się rozpoczęły. Chociaż przedstawione globalne zasoby nie są podzielone według państw, potencjał technicznie możliwych do wydobycia zasobów, na poziomie $87000 \mathrm{mln}$ ton, to prawie $40 \%$ globalnych potwierdzonych zasobów wydobywalnych ropy. Ujawniono szacunki dla wybranych krajów, w tym Chin (41 $000 \mathrm{mln}$ ton) i Wenezueli (34 $000 \mathrm{mln}$ ton), które to dominują w ilości zasobów (dane dla Stanów Zjednoczonych to jedynie $3000 \mathrm{mln}$ ton). W miarę postępów w pracach poszukiwawczych wielkości oszacowanych zasobów i ich zasięg geograficzny będą prawdopodobnie rosnąć, chociaż badanie z 2013 roku przeprowadzone przez EIA (2013c) podaje mniejsze wartości globalnych zasobów technicznie wydobywalnej ropy z lupków, szacując je na poziomie $47000 \mathrm{mln}$ ton. Rosji przypada największy udział na poziomie 22\%, następne są Stany Zjednoczone z 17\%, Chiny z 9\%, Argentyna i Libia z 8\% oraz Wenezuela i Meksyk z udziałem po 4\%. Różnice w szacunkach poszczególnych badań wskazują na niepewność, złożoność i subiektywizm właściwy tego typu ocenom, ale wszystkie one upoważniają do stwierdzenia, że globalne zasoby ropy w formacjach łupkowych są ogromne.

Z przyczyn omówionych powyżej, oddziaływanie „hupków” w skali światowej będzie nierównomierne i rozłożone w czasie. Według aktualnych, bardziej ostrożnych przewidywań specjalistów do spraw energetyki, wspomniany wpływ będzie w pełni odczuwalny dopiero w latach trzydziestych dwudziestego pierwszego wieku. Jednakże nie można zapominać zadziwiającej nagłości i rozmachu rozwoju, jaki dokonał się w Stanach Zjednoczonych w ostatnim dziesięcioleciu. Podobnych niespodzianek nie można więc wykluczyć w przypadku innych państw posiadających znaczące zasoby.

Poniższa prognoza jest niczym więcej niż eksperymentem myślowym, mającym za zadanie ocenić ewentualny wpływ międzynarodowego rozprzestrzenienia się rewolucji 
łupkowej (jak przedstawiono $\mathrm{w}$ tabeli 2). Rozpoczyna go podsumowanie osiągnięć USA w latach 2005-2013, na wczesnym etapie rewolucji, po czym następuje asekuranckie pominięcie wszystkich przyszłych osiągnięć USA, które niewątpliwie nadejdą. Z około $9 \%$ udziałem $w$ globalnych zasobach gazu $w$ formacjach łupkowych (EIA 2013c) oraz 4\% udziałem w zasobach ropy w formacjach łupkowych (DERA 2012) Stany Zjednoczone w ciągu ośmiu lat rozszerzyły swoją produkcję o 196 Mtoe gazu i 186 Mt ropy.

Tabela 2. Spekulacje na temat wpływu łupków poza USA. 2015-2035 [Mtoe]

Table 2. Speculative non-US shale impact. 2015-2035 [Mtoe]

\begin{tabular}{|c|c|c|c|c|c|}
\hline $\begin{array}{c}\text { Wyszcze- } \\
\text { gólnienie }\end{array}$ & $\begin{array}{c}\text { Światowe } \\
\text { wydobycie } \\
\text { w } 2012 \mathrm{r} .\end{array}$ & $\begin{array}{c}\text { Światowy } \\
\text { wzrost, } \\
20 \text { lat } \\
(1991-201)\end{array}$ & $\begin{array}{c}\text { Udział Stanów } \\
\text { Zjednoczonych } \\
\text { w zasobach } \\
\text { łupkowych } \\
{[\%]}\end{array}$ & $\begin{array}{c}\text { Wzrost } \\
\text { wydobycia } \\
\text { W USA, } \\
8 \text { lat } \\
(2005-201)\end{array}$ & $\begin{array}{c}\text { Wzrost } \\
\text { wydobycia } \\
\text { (reszta świata), } \\
20 \text { lat } \\
(2015-2035)\end{array}$ \\
\hline Gaz ziemny & 3034 & 1130 & 9 & 196 & 2170 \\
\hline Ropa naftowa & 4120 & 850 & 4 & 186 & 4650 \\
\hline
\end{tabular}

Załóżmy więc, że reszta świata będzie równie skuteczna w wykorzystaniu własnych zasobów w latach 2015-2035 jak Stany Zjednoczone w latach 2005-2013, tj. przy zachowaniu znacznego opóźnienia i mniejszej niż połowa prędkości w porównaniu do USA. Należałoby wówczas przyjać, przy ostrożnych wyliczeniach, że w 2035 roku reszta świata osiagnęłaby wydobycie gazu z łupków na poziomie 2170 Mtoe, podczas gdy wydobycie ropy z łupków w tym samym roku wyniosłaby $4650 \mathrm{Mt}$.

Znaczenie tych wzrostów wydobycia można mierzyć na różne sposoby, ale są one naprawdę imponujące. Przewidywana ekspansja wydobycia gazu odpowiada $71 \%$ obecnego wydobycia w skali światowej; wydobycie ropy z łupków dla krajów reszty świata za 2035 rok jest większe niż całkowite globalne wydobycie ropy naftowej w 2012 roku! Prognozy wzrostu wydobycia gazu z łupków dla krajów reszty świata na okres 20 lat podane w tabeli są dwa razy większe od światowego wzrostu wydobycia w poprzednich 20 latach; dla ropy są one ponad pięć razy większe! Należy pamiętać, że przyszłe wzrosty wydobycia z konwencjonalnych złóż, takie jak wynikające z najnowszych odkryć gazu we wschodniej części Morza Śródziemnego, powinny zostać dodane do przedstawionych w tabeli $2 \mathrm{w}$ celu uzyskania łącznego globalnego wydobycia w 2035 roku. Jeśli te przewidywania miałyby się urzeczywistnić, w ciaggu najbliższych dwudziestu lat nastąpiłaby wręcz rewolucyjna zmiana - prawdziwy przełom dla rynków gazu i ropy.

Czy powyższy eksperyment ma w ogóle sens? Wydaje się, że z pewnością jest on przydatny jako swego rodzaju rozszerzenie aktualnych prognoz i przewidywań dotyczących przyszłych wydarzeń. 


\section{Konsekwencje polityczne pomyślnie dojrzewającej globalnej rewolucji lupkowej}

Dynamiczny wzrost wydobycia będący wynikiem udanej rewolucji łupkowej może spowodować liczne konsekwencje. Przy wszystkich wątpliwościach co do tego gdzie i w jaki sposób rewolucja wpłynie na wydobycie, wydaje się, że wychodzenie poza ogólny szkic podsumowujący prawdopodobne skutki jest bezcelowe.

Pierwszym i prawdopodobnie najważniejszym następstwem będzie presja na obniżenie wysokich cen gazu na rynkach regionalnych poza Ameryką Północną oraz światowych cen ropy. Wzrost i dywersyfikacja geograficzna dostaw będzie promować konkurencję między dostawcami i sprawi, że manipulowanie rynkiem w celu uzyskania korzyści przez producentów stanie się trudniejsze, tak samo jak wykorzystywanie przez rządy handlu energią do realizacji ich celów politycznych.

Wiele krajów wydobywających paliwa kopalne stanęłoby w obliczu zmniejszonych dochodów z eksportu. Kraje, których eksport jest zdominowany przez te paliwa, a których własna eksploatacja z łupków nie zrekompensowałaby strat w dochodach z powodu niższych cen ropy i gazu, stanęłyby w obliczu konieczności dywersyfikacji gospodarczej, a niekiedy bolesnych korekt makroekonomicznych w celu zbilansowania gospodarki. Wybrani przedsiębiorcy eksploatujący złoża łupków mogliby czerpać korzyści podobne do tych, jakie były udziałem USA w ostatnich latach.

Kraje importujące energię, choć niekoniecznie jej odbiorcy, skorzystałyby z niższych cen. Ustalając opłaty przywozowe oraz podatki konsumpcyjne, rządy krajów importerów mogłyby zasilić swoje budżety i zmniejszyć wzrost zapotrzebowania na energię.

Producenci węgla na świecie napotkają zaostrzoną konkurencję ze strony gazu i ropy naftowej, co doprowadzi do kurczenia się rynku i niższych cen węgla. Producenci o zbyt wysokich kosztach produkcji węgla będą zmuszeni do zamykania działalności.

Wysiłki na rzecz rozwoju odnawialnych źródeł energii w celu ustabilizowania klimatu i bezpieczeństwa energetycznego staną się bardziej kosztowne w wyniku rewolucji łupkowej. W obliczu spadku cen kopalin, polityka skierowana na zapewnienie większych dotacji na energię wiatrową, solarną i biopaliwa byłaby niezbędna, aby utrzymać ich pozycję na rynku. Tymczasem zwiększony udział gazu ziemnego na rynku, a więc najczystszego paliwa kopalnego, dałby szansę na zmniejszenie emisji dwutlenku węgla w porównaniu z węglem i ropą naftową. W Europie, obniżone ceny węgla mogą doprowadzić do większego wykorzystania go w produkcji energii elektrycznej. Chociaż nie wpłynie to na łączne emisje dwutlenku węgla (ponieważ są one określane przez pułapy emisji w ramach systemu handlu uprawnieniami do emisji), to prawdopodobnie zwiększy cenę uprawnień do emisji.

Trudno zgłębić międzynarodowe reperkusje polityczne wynikłe z malejącego znaczenia Bliskiego Wschodu jako dominującego dostawcy paliw kopalnych. Dyplomatyczna i wojskowa obecność USA w regionie może być kwestionowana, gdy zależność tego kraju od gazu i ropy naftowej z Bliskiego Wschodu ulegnie zmniejszeniu. Prezentowana analiza ma 
charakter ekonomiczny i nie jest w stanie określić prawdopodobnych reakcji i reperkusji politycznych w odpowiedzi na częściowe wycofanie się Stanów Zjednoczonych z regionu. Co więcej, możliwe jest, że ropa z Bliskiego Wschodu zyska zwiększony udział na wciąż rozwijających się rynkach azjatyckich, gdzie przemysł łupkowy prawdopodobnie nie rozwinie się znacząco przez kilka następnych dziesięcioleci. Mogą mieć miejsce ważne reakcje polityczne i gospodarcze ze strony potężnych krajów azjatyckich, np. Chin, które zmierzają do zabezpieczenia dostaw ropy z Bliskiego Wschodu. Jeśli chodzi o gaz z łupków to jest wielce prawdopodobne, że Bliski Wschód także posiada ogromne jego zasoby. Okazałoby się to korzystne dla zaspokojenia szybko rosnącej konsumpcji krajowej.

Rysuje się więc bardzo ciekawa przyszłość.

\section{REFERENCES}

Abiteboul, J. 2012. What is the Time Line for LNG Exports from the USA? Presentation to the Flame Conference, Amsterdam, 12 April.

Aguilera i in. 2012 - Aguilera, R.F., Ripple, R.D. i Aguilera, R. 2012. Link between Rocks, Hydraulic Fracturing, Economics, Environment, and the Global Gas Portfolio. SPE Canadian Unconventional Resources Conference. CURC 2, 1044-1068

BP Annual. BP Statistical Review of World Energy.

Brantley, S.L. i Meyendorff, A. 2013. The Facts on Fracking. The New York Times, March 13. [Online] Available at: http://www.nytimes.com/2013/03/14/opinion/global/the-facts-on-fracking.html

Burnham i in. 2012 - Burnham, A., Han, J., Clark, C.E., Wang, M., Dunn, J.B. i Palou-Rivera, I. 2012. Life-cycle greenhouse gas emissions of shale gas, natural gas, coal, and petroleum. Environmental Science and Technology 46, 619-627.

CAPP 2013. Canadian Natural Gas Production Forecast. Canadian Association of Petroleum Producers, April 13 [Online] Available at: http://www.capp.ca/forecast/Pages/default.aspx.

CERI 2012. Canadian Oil Sands Supply Costs and Development Projects 2011-2045, Canadian Energy Research Institute Study 128, Calgary, Canada.

Dahl, C.A. 2004. International energy markets: understanding pricing, policies, and profits, PennWell Corporation, Tulsa, Oklahoma.

DERA 2012. Energy Study: Reserves, Resources and Availability of Energy Resources 2012. Deutsche Rohstoffagentur, Hannover.

Ebinger, C. i Avasarala, G. 2013. The Case for US LNG Exports. Oxford Energy Forum, Issue 91.

EIA 2011a. Review of Emerging Resources: US Shale Gas and Shale Oil Plays. Energy Information Administration, Washington DC.

EIA 2011b. World Shale Gas Resources: An Initial Assessment of 14 Regions Outside the US. Energy Information Administration, Washington DC, April.

EIA 2013a. Annual Energy Outlook, Energy Information Administration, Washington DC.

EIA 2013b. Monthly Energy Review. Energy Information Administration, Washington DC, April.

EIA 2013c. Technically Recoverable Shale Oil and Shale Gas Resources: An Assessment of 137 Shale Formations in 41 Countries Outside the United States. Energy Information Administration, Washington DC, June.

EPRINC 2011. Natural Gas Industry Fakes the Moon Landing. Briefing Memorandum,

Energy Policy Research Foundation, Washington DC, July 1.

EPRINC 2013. Prospects for LNG Exports from North America. Presentation at JOGMEC Petroleum Seminar. Tokyo, February 7.

Fan Gao 2012. Will There Be a Shale Gas Revolution in China by 2020? NG61, Oxford Institute for Energy Studies, April. 
Fattouh, B. 2013. The US Tight Oil Revolution: What Kind of a Revolution? Oxford Institute for Energy Studies, presentation at the Saudi Association for Energy Economics, May 28.

Fisher, K. i Warpinski, N. 2011. Hydraulic fracture-height growth. SPE paper 145949. Annual Technical Conference and Exhibition, Denver, Colorado: October 30-November 2.

FT Alphaville 2012. US Shale Oil Abundance: Bernstein vs the IEA, Financial Times Alphaville, November 19 [Online] Avaliable at: http://ftalphaville.ft.com/2012/11/19/1266853/us-shale-oil-abundance-bernstein-vs-the-iea/

FT 2013a. Oil Tanker Trade Soars on Back of US Boom. Financial Times, May 13.

FT 2013b. Chevron back in Argentina with \$1.2 billion deal. Financial Times, July 17.

GEA 2012. Global Energy Assessment: Toward a Sustainable Future, Cambridge University Press, United Kingdom.

Hasset, K. i Mathur, A. 2013. Benefits of Hydraulic Fracking. Oxford Energy Forum, Issue 91.

Howarth i in. 2011 - Howarth, R.V., Santoro, R. i Ingraffea, A. 2011. Methane and the greenhouse-gas footprint of natural gas from shale formations. Letter published with open access at Springerlink.com, 13 March.

Hunter, T. 2011. Regulation of Shale, Coal Seam and Tight Gas Activities in Western Australia. Bond University, Queensland, July.

IEA 2009. World Energy Outlook. International Energy Agency, Paris.

IEA 2011a. Medium Term Oil and Gas Markets. International Energy Agency, Paris.

IEA 2011b. Are we Entering the Golden Age of Gas? International Energy Agency, Paris.

IEA 2012a. World Energy Outlook. International Energy Agency, Paris.

IEA 2012b. Medium Term Oil Market Report, International Energy Agency, Paris.

IEA 2013. Resources to Reserves, International Energy Agency, Paris.

IHS 2012. America's Energy Future: The Unconventional Oil and Gas Revolution and the US Economy. Englewood, Colorado, USA, October.

Jiang i in. 2011 - Jiang, M., Griffin, M., Hendrickson, C., Jaramillo, P., VanBriesen, J. i Venkatesh, A. 2011. Life cycle greenhouse gas emissions of Marcellus shale gas. Environmental Research Letters 6 (3).

Martin, A. 2009. Appropriate Hydraulic Fracture Technologies for Mature Oil and Gas Formations. SPE Distinguished Lecturer Program, 2008-2009 Season.

Maugeri, L. 2013. The Shale Oil Boom: A US Phenomenon. Discussion Paper \#2013-05, Harvard Kennedy School, June.

Medlock, K.B. 2012. Shale Gas, Emerging Fundamentals, and Geopolitics. Presentation at James A Baker III Institute for Public Policy, Rice University, June 14.

NERA Economic Consulting 2012. Macroeconomic Impacts of LNG Exports from the United States. Washington D.C., USA, December.

Nicot, J.P. i Scanlon, B.R. 2012. Water Use for Shale Gas Production in Texas, US. Environmental Science and Technology 46, 3580-3586.

Orangi i in. 2011 - Orangi, A., Nagarajan, N.R., Honarpour, M.M. i Rosenzweig, J. 2011. Unconventional Shale Oil and Gas - Condensate Reservoir Production, Impact of Rock, Fluid, and Hydraulic Fractures. SPE Paper 140536, SPE Hydraulic Fracturing Technology Conference and Exhibition, Woodlands, Texas, January 24-26.

O’Sullivan, F. i Paltsev, S. 2012. Shale Gas Production: Potential Versus Actual Greenhouse Gas Emissions. Environmental Research Letters 7 (4).

PGC 2013. Potential Gas Committee Press release, Colorado School of Mines, Golden, Co, April 9.

Platts 2013. US DOE approves Dominion Cove Point plans to export LNG to non-FTA countries. Platts McGraw Hill Financial, September 11.

Polish Ministry of Treasury 2013. Economic News, Warsaw, April 19.

Ripple, R.D. 2011. There's more to coalseam gas than Gasland. The Conversation, May 26. [Online] Avaliable at: http://theconversation.com/theres-more-to-coal-seam-gas-than-gasland-1477

Robinson, D. i Qinhua, X. 2013. OIES-Renmin Roundtable Conference on Implications for China of North American Energy Independence: Summary of Discussions. Oxford Institute for Energy Studies and Renmin University of China, Beijing, Mar 27. 
Rystad Energy 2012. North American Shale Analysis, Oslo, Norway. [Online] Avaliable at: http://www.rystadenergy.com/ResearchProducts/NASAnalysis

Schlumberger 2013. Conventional Sandstone Stimulation, Schlumberger Ltd, Houston. [Online] Avaliable at: http://www.slb.com/services/completions/stimulation/sandstone.aspx

SPE News 2013. Australian shale potential No. 1. SPE News Australasia, May 21. [Online] Avaliable at: http://www.spenewsaustralasia.org/article.aspx? $\mathrm{p}=1 \& \mathrm{id}=2020$

Stevens, P. 2012. The „Shale Gas Revolution”: Developments and Changes. Chatham House Briefing Paper, London.

Tucker, A. 2012. The New Power Map, World Politics After the Boom in Unconventional Energy. Foreign Affairs, December 19.

US DOE 2011. Shale Gas Production Subcommittee Second Ninety Day Report. Secretary of Energy Advisory Board, US Department of Energy, Washington DC.

Vihma, A. 2013. The Shale Gas Boom. FIIA Briefing Paper 122, Helsinki, February.

\section{REWOLUCJA LUPKOWA: ŚWIATOWE RYNKI GAZU I ROPY NAFTOWEJ}

W WARUNKACH TRANSFORMACJI

Słowa kluczowe

gaz i ropa naftowa z łupków, geopolityka, makroekonomia

Streszczenie

Rewolucja łupkowa, opierająca się na gazie i ropie z łupków, nieoczekiwanie i jednoznacznie zaczęła zmieniać krajobraz energetyczny Stanów Zjednoczonych. Należy się spodziewać jej rozszerzenia poza terytorium Stanów Zjednoczonych, z daleko idącymi konsekwencjami nie tylko dla globalnej energetyki, ale także dla makroekonomii i polityki wielu krajów. Celem niniejszej pracy jest lepsze zrozumienie uwarunkowań, które doprowadziły do wyżej wspomnianej rewolucji, ocena metod eksploatacji oraz związanych z nimi zagrożeń dla środowiska naturalnego, przedstawienie scenariuszy, jakich można racjonalnie oczekiwać w nadchodzących dekadach, jak i próba zarysu wpływu dojrzewającej rewolucji łupkowej na polityczne i ekonomiczne decyzje dokonywane przez kraje eksportujące energię, jak również ją importujące. Prognozuje się, że najbliższe dwie dekady w Stanach Zjednoczonych dadzą początek szeroko zakrojonej ekspansji pod względem aktywności na rynku gazu i ropy z łupków. W skali globalnej, liderami przemysłu łupkowego mogą być te kraje, które są już znaczącymi producentami gazu i ropy naftowej. Ustanowienie ramowych założeń mających umożliwić i wspierać bezpieczny rozwój przemysłu łupkowego jest warunkiem koniecznym dla rozpoczęcia eksploatacji łupków. Najważniejszą konsekwencją udanej rewolucji łupkowej będzie presja na obniżkę cen gazu i węgla na rynkach regionalnych oraz ropy naftowej na rynkach globalnych. 
THE SHALE REVOLUTION: GLOBAL GAS AND OIL MARKETS UNDER TRANSFORMATION

$$
\text { Key words }
$$

shale gas and oil, geopolitics, macro-economy

\section{Abstract}

The shale gas and oil revolution has unexpectedly and forcefully begun to change the energy landscape in the United States. It is expected to spread beyond the US, with far reaching implications for the global energy map, but also for the macro-economy and politics of many countries. The purpose of this paper is to bring a better understanding to what prompted the revolution, to assess the production methods and associated environmental concerns, to speculate what can reasonably be expected in coming decades, and to sketch the full impact of a ripening shale revolution on the emerging economic and political policy choices for energy exporting and importing countries. We find that a large scale expansion can be expected in US shale gas and oil activities in the coming two decades. Globally, the shale leaders are likely to be countries that are already significant gas and oil producers. Setting up a policy framework to allow and promote shale development in a safe manner is a necessity for the launch of shale exploitation. The most important implication of a successful shale revolution would arguably be a downward pressure on gas and coal prices in regional markets and on the global oil price. 